Case Report

\title{
Diagnosis and Treatment of Esophageal Granular Cell Tumor: A Case Report and Review of the Literature
}

\author{
Ramin Niknam, ${ }^{1}$ Kamran Bagheri Lankarani, ${ }^{2}$ and Bita Geramizadeh ${ }^{3}$ \\ ${ }^{1}$ Gastroenterohepatology Research Center, Shiraz University of Medical Sciences, Shiraz, Iran \\ ${ }^{2}$ Health Policy Research Center, Shiraz University of Medical Sciences, Shiraz, Iran \\ ${ }^{3}$ Department of Pathology, Transplant Research Center, Shiraz University of Medical Sciences, Shiraz, Iran \\ Correspondence should be addressed to Ramin Niknam; niknamramin@yahoo.com
}

Received 19 September 2017; Accepted 7 November 2017; Published 22 November 2017

Academic Editor: Naohiko Koide

Copyright (c) 2017 Ramin Niknam et al. This is an open access article distributed under the Creative Commons Attribution License, which permits unrestricted use, distribution, and reproduction in any medium, provided the original work is properly cited.

Gastrointestinal granular cell tumors are uncommon. The most common site of gastrointestinal granular cell tumor (GCT) is esophagus. We report a case of esophageal GCT incidentally diagnosed by endoscopy. The lesion was evaluated by endoscopic ultrasonography and resected using the endoscopic technique without complication.

\section{Introduction}

Granular cell tumor (GCT) was described in 1926 by Abrikossoff [1]. These tumors may arise in different organs [2]. The origin of GCTs is the Schwann cell. These tumors consist of fusiform and polygonal cells in compact nests with dark nuclei and abundant eosinophilic granular cytoplasm $[3,4]$.

The most common site of gastrointestinal GCTs is esophagus that only a few cases have been reported in the literature [4-6]. In this report, we described a case of esophageal GCT treated by the endoscopic technique. We also review some literature on diagnosis and management of GCTs.

\section{Case Report}

A 50-year-old woman presented to our center with dyspepsia from three months prior to evaluation. Past medical history was unremarkable. The physical examination was normal. Upper gastrointestinal endoscopy was performed for evaluation of cause of dyspepsia. Endoscopy identified a firm submucosal yellow lesion, measuring approximately $10 \mathrm{~mm}$ and located $30 \mathrm{~cm}$ distal from the incisor teeth (Figure 1). The stomach and duodenum were normal. Biopsies by forceps were taken from the esophageal lesion. The histologic assessment was in favor of GCT.
Endoscopic ultrasonography (EUS) was performed by linear echo with frequency of $10 \mathrm{MHZ}$. EUS identified a submucosal lesion with a diameter of $12 \mathrm{~mm}$. It was a nonhomogeneous hyperechoic solid lesion with clear border with no extension to muscularis layer and without mediastinal adenopathies (Figure 1).

The patient was considered for endoscopic resection of lesion. After deep sedation with intravenous Propofol (Lipuro-1\%), submucosal injection of $5 \mathrm{ml}$ diluted epinephrine solution $(0.01 \mathrm{mg} / \mathrm{ml})$ with $0.5 \mathrm{ml}$ methylene blue was done using a sclerotherapy needle (ENDO-FLEX-Germany). After creation of the submucosal fluid bulging, the resection of lesion was performed using a monofilament rotatable polypectomy snare (Boston; $20 \mathrm{~mm}$; output setting: cut 40 watts; coagulation 40 watts) without any complication (Figure 2). The resected specimen was removed by basket. The size of specimen was $12 \times 5 \mathrm{~mm}$ with yellow color (Figure 2). The specimen was fixed in $10 \%$ formalin and transferred to the lab for histologic assessment.

In histologic examination, the diagnosis of GCT was confirmed. Histological analysis of specimen revealed nests of medium-sized cells with abundant eosinophilic granular cytoplasm with bland looking nuclei without any atypia or pleomorphism (Figure 3). 


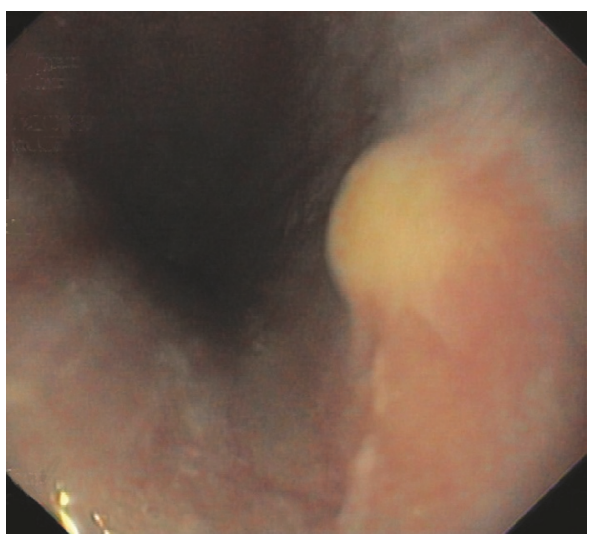

(a)

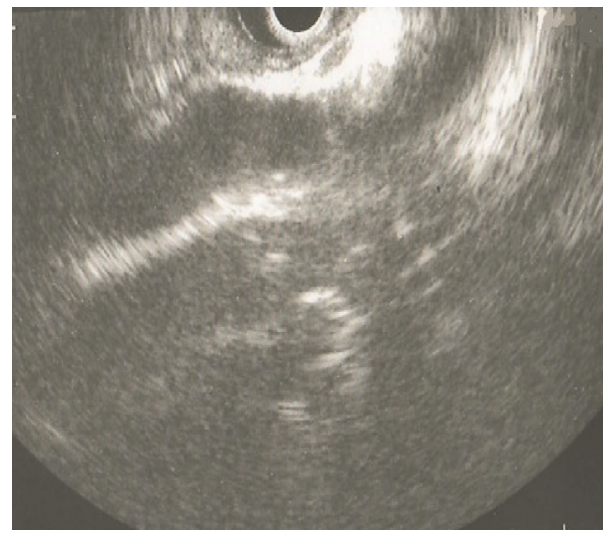

(b)

Figure 1: Endoscopic view of an elevated yellow submucosal lesion in esophagus (a). Endosonographic image showed a nonhomogeneous hyperechoic submucosal lesion with a diameter of $12 \mathrm{~mm}$ and without extension to muscularis layer (b).

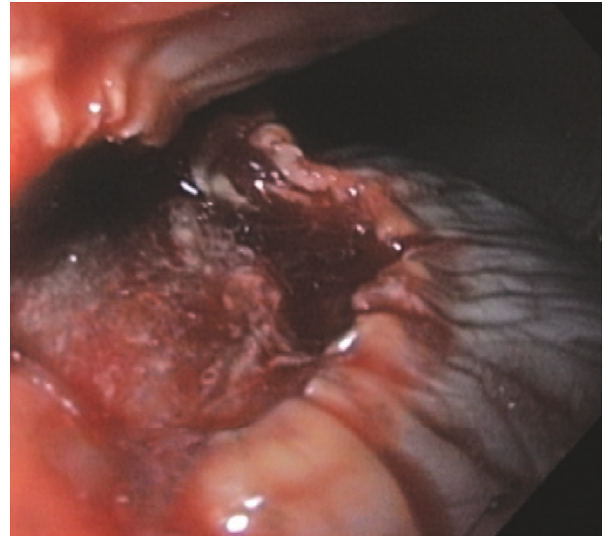

(a)

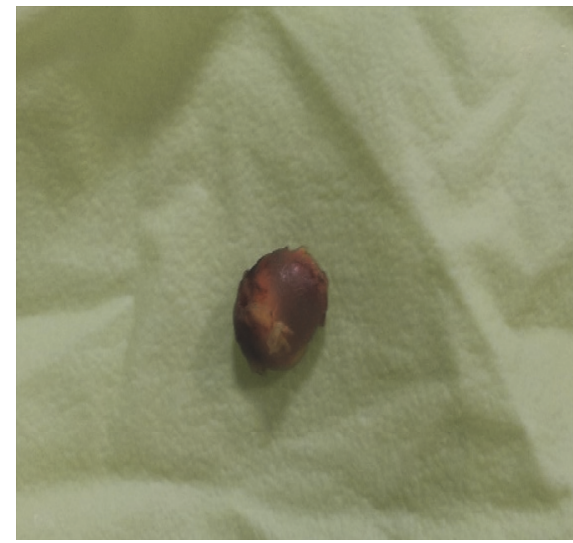

(b)

Figure 2: Endoscopic view of the esophagus after endoscopic treatment of tumor (a). Gross appearance of the tumor after endoscopic treatment (b).

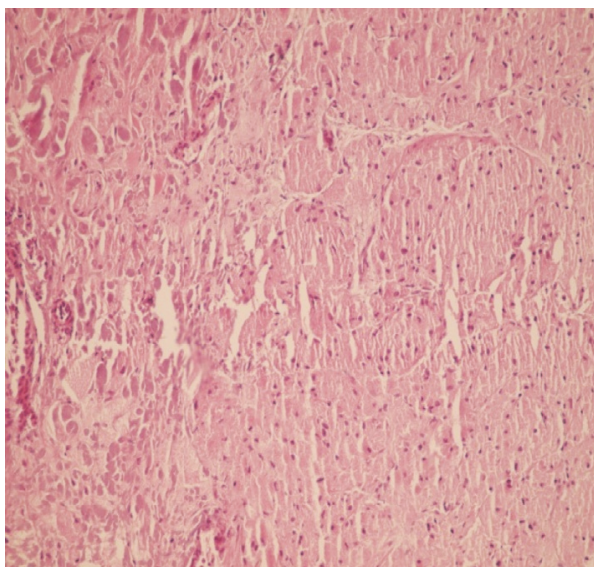

(a)

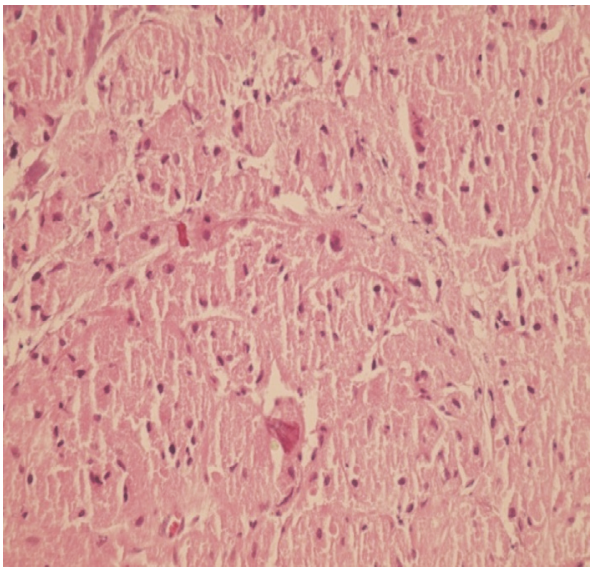

(b)

FIGURE 3: Section of the esophageal wall (a) showed nests of medium-sized cells with abundant eosinophilic granular cytoplasm (H\&E $\times 100)$. High power view of the tumor in the esophageal wall (b) showed the above-mentioned cells with bland looking nuclei without any atypia or pleomorphism $(\mathrm{H} \& \mathrm{E} \times 400)$. 
Follow-up endoscopy 9 months after removal of tumor showed complete healing of the site of resection in esophagus.

\section{Discussion}

The most common site of GCTs is tongue although these tumors may arise in other organs [2]. Gastrointestinal GCTs are uncommon. The most common site of gastrointestinal GCTs is esophagus that approximately 270 cases have been reported in the literature [4-6]. Esophageal GCTs usually appear as a white-gray to yellow submucosal mass that may be mistaken for other lesions such as lipoma, leiomyoma, and cyst $[2,4]$.

Esophageal GCTs are usually asymptomatic and found incidentally during endoscopy. The tumor may present with dysphagia when it is larger than $1 \mathrm{~cm} \mathrm{[2,} \mathrm{4,} \mathrm{7-9].}$

Although most esophageal GCTs have a benign clinical course, malignant tumors were reported in the literature. Malignant GCTs are usually larger than $4 \mathrm{~cm}[4,10]$ with rapid growth and invasion of the adjacent tissues and high recurrence rate after excision $[2,11]$. Tumor cell spindling and necrosis, increased mitotic activity with pleomorphism, and large nucleoli with high nuclear to cytoplasmic ratio are histologic evidence in favor of malignant GCTs [12].

EUS is useful technique for deciding the type of management of GCTs $[4,13]$. EUS pattern of esophageal GCTs appears as a solid hypoechoic lesion with a smooth borders and mildly inhomogeneous echo pattern $[2,14]$. They usually originate in the muscularis mucosa or submucosal layer of the esophagus. For evaluation of the role of EUS in the diagnosis of GCTs, a study in 15 patients with esophageal GCTs was performed by Palazzo et al. They concluded that EUS can contribute to planning the management of GCTs [14].

In order to compare EUS findings and histopathological analysis of resected submucosal lesions, Yazumi et al. studied 18 consecutive patients with esophageal submucosal tumors (5 GCTs and 13 leiomyomas). They concluded that EUS is useful for differentiating esophageal GCTs from leiomyomas [15].

The optimum management of GCTs is controversial [12]. Endoscopic follow-up for asymptomatic tumors less than $10 \mathrm{~mm}$, endoscopic resection for tumors $10-20 \mathrm{~mm}[4,12,16$, 17], and surgical excision for tumors more than $20 \mathrm{~mm}$ or symptomatic patient $[12,18]$ are generally recommended.

Similar to our case, Nakajima et al. reported a case of esophageal GCT diagnosed by endoscopic biopsy and EUS that treated by endoscopic submucosal dissection. They concluded that ESD is a safe and accurate procedure for GCTs [4]. De Ceglie et al. also reported a case of esophageal GCT diagnosed by endoscopic biopsy and EUS that was treated by EMR without any complication [2].

Similar to some reports, GCT in our patient was incidentally diagnosed by endoscopy $[7,9]$. Because of the size of tumor $10-20 \mathrm{~mm}$, similar to some reports, we treated the tumor by endoscopic resection $[4,16,17]$.

Based on our experience and other published reports $[2,4,14]$ we recommend that the submucosal lesion of esophagus can be evaluated by biopsy and EUS. If biopsy and/or EUS finding shows high possibility for diagnosis of GCT, endoscopic treatment can be safely scheduled for the tumors with size $10-20 \mathrm{~mm}$.

\section{Conflicts of Interest}

The authors declare that there are no conflicts of interest regarding the publication of this paper.

\section{Authors' Contributions}

Ramin Niknam was the physician in charge and assisted in study supervision, endoscopic resection, and manuscript writing. Kamran Bagheri Lankarani conducted the endoscopic ultrasonography evaluation. Bita Geramizadeh helped in histology evaluation.

\section{Acknowledgments}

The authors would like to acknowledge the Center for Development of Clinical Research of Nemazee Hospital, Shiraz University of Medical Sciences, Shiraz, Iran, for editorial assistance.

\section{References}

[1] A. Abrikossoff, "Über Myome ausgehend von der quergestreiften willkürlichen Muskulatur," Virchows Archiv für pathologische Anatomie und Physiologie und für klinische Medizin, vol. 260, no. 1, pp. 215-233, 1926.

[2] A. De Ceglie, B. Gatteschi, S. Blanchi, F. Scotto, A. Pellecchia, and M. Conio, "Esophageal granular cell tumor treated by endoscopic mucosal resection. A case report and review of the literature," Digestive Diseases and Sciences, vol. 50, no. 10, pp. 1875-1879, 2005.

[3] A. Giacobbe, D. Facciorusso, P. Conoscitore, F. Spirito, M. M. Squillante, and M. Bisceglia, "Granular cell tumor of the esophagus," American Journal of Gastroenterology, vol. 83, no. 12, pp. 1398-1400, 1988.

[4] M. Nakajima, H. Kato, H. Muroi et al., "Esophageal granular cell tumor successfully resected by endoscopic submucosal dissection," Esophagus, vol. 8, no. 3, pp. 203-207, 2011.

[5] E. E. Lack, G. F. Worsham, M. D. Callihan et al., "Granular cell tumor: a clinicopathologic study of 110 patients," Journal of Surgical Oncology, vol. 13, no. 4, pp. 301-316, 1980.

[6] S. Perçinel, B. Savaş, G. Yilmaz et al., "Granular cell tumor of the esophagus: three case reports and review of the literature," The Turkish Journal of Gastroenterology, vol. 19, no. 3, pp. 184-188, 2008.

[7] J. R. Goldblum, T. W. Rice, G. Zuccaro, and J. E. Richter, "Granular cell tumors of the esophagus: a clinical and pathologic study of 13 cases," The Annals of Thoracic Surgery, vol. 62, no. 3, pp. 860-865, 1996.

[8] B. Geramizadeh and P. Ali Nowshadi, "Photoclinic," Archives of Iranian Medicine, vol. 16, no. 1, Article ID 013161, pp. 59-60, 2013.

[9] T. Toyanaga, M. Man-I, D. Ivanov et al., "The results and limitations of endoscopic submucosal dissection for colorectal tumors," Acta Chirurgica Iugoslavica, vol. 55, no. 3, pp. 17-23, 2008. 
[10] J. C. Fanburg-Smith, J. M. Meis-Kindblom, R. Fante, and L.-G. Kindblom, "Malignant granular cell tumor of soft tissue: diagnostic criteria and clinicopathologic correlation," The American Journal of Surgical Pathology, vol. 22, no. 7, pp. 779-794, 1998.

[11] J. Orlowska, J. Pachlewski, A. Gugulski, and E. Butruk, "A conservative approach to granular cell tumors of the esophagus: four case reports and literature review," American Journal of Gastroenterology, vol. 88, no. 2, pp. 311-315, 1993.

[12] L. De Rezende, A. J. Lucendo, and H. Álvarez-Argüelles, "Granular cell tumors of the esophagus: report of five cases and review of diagnostic and therapeutic techniques," Diseases of the Esophagus, vol. 20, no. 5, pp. 436-443, 2007.

[13] D. U. Kim, G. H. Kim, D. Y. Ryu et al., "Endosonographic features of esophageal granular cell tumors using a high-frequency catheter probe," Scandinavian Journal of Gastroenterology, vol. 46, no. 2, pp. 142-147, 2011.

[14] L. Palazzo, B. Landi, C. Cellier et al., "Endosonographic features of esophageal granular cell tumors," Endoscopy, vol. 29, no. 9, pp. 850-853, 1997.

[15] S. Yazumi, R. Takahashi, T. Kajiyama et al., "Comparison of histological analysis and endosonographic features in esophageal granular cell tumors," Digestive Endoscopy, vol. 15, no. 4, pp. 284-288, 2003.

[16] S. Okahara, S. Tanaka, and K. Haruma, "A case of granular cell tumor of the esophagus resected endoscopically," The Hiroshima Medical Association, vol. 48, pp. 810-814, 1995.

[17] I. Yasuda, E. Tomita, K. Nagura, Y. Nishigaki, O. Yamada, and H. Kachi, "Endoscopic removal of granular cell tumors," Gastrointestinal Endoscopy, vol. 41, no. 2, pp. 163-167, 1995.

[18] D. S. Coutinho, J. Soga, T. Yoshikawa, K. Miyashita, O. Tanaka, K. Sasaki et al., "Granular cell tumors of the esophagus: a report of two cases and review of the literature," The American Journal of Gastroenterology, vol. 80, pp. 758-762, 1985. 


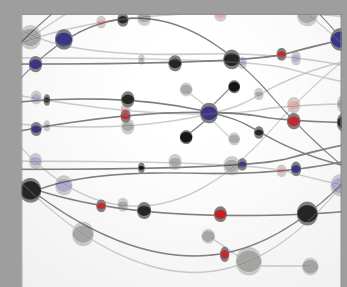

The Scientific World Journal
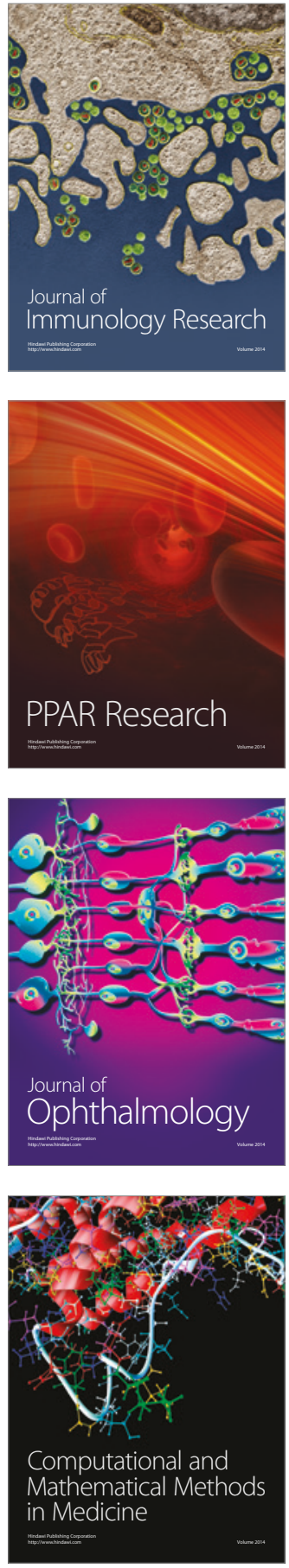

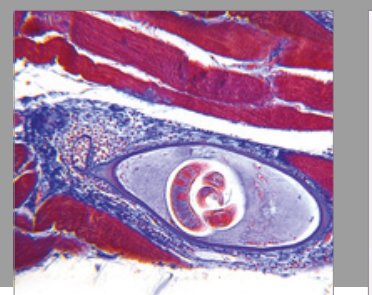

Gastroenterology Research and Practice
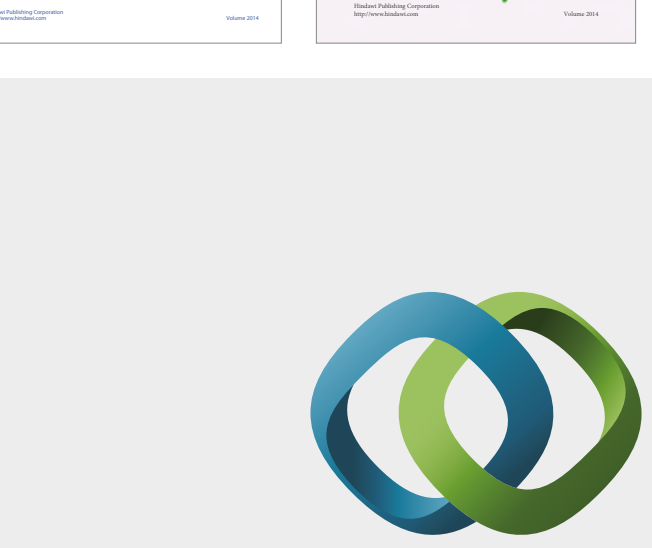

\section{Hindawi}

Submit your manuscripts at

https://www.hindawi.com
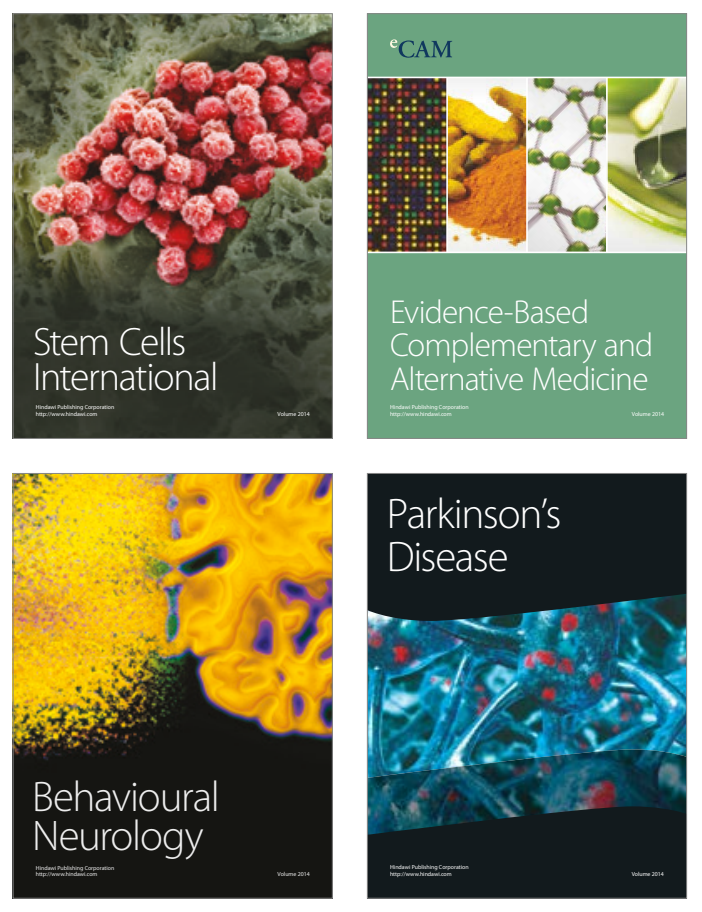
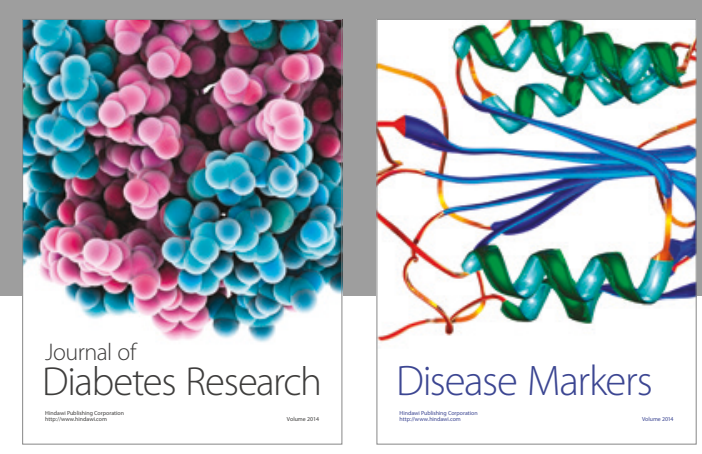

Disease Markers
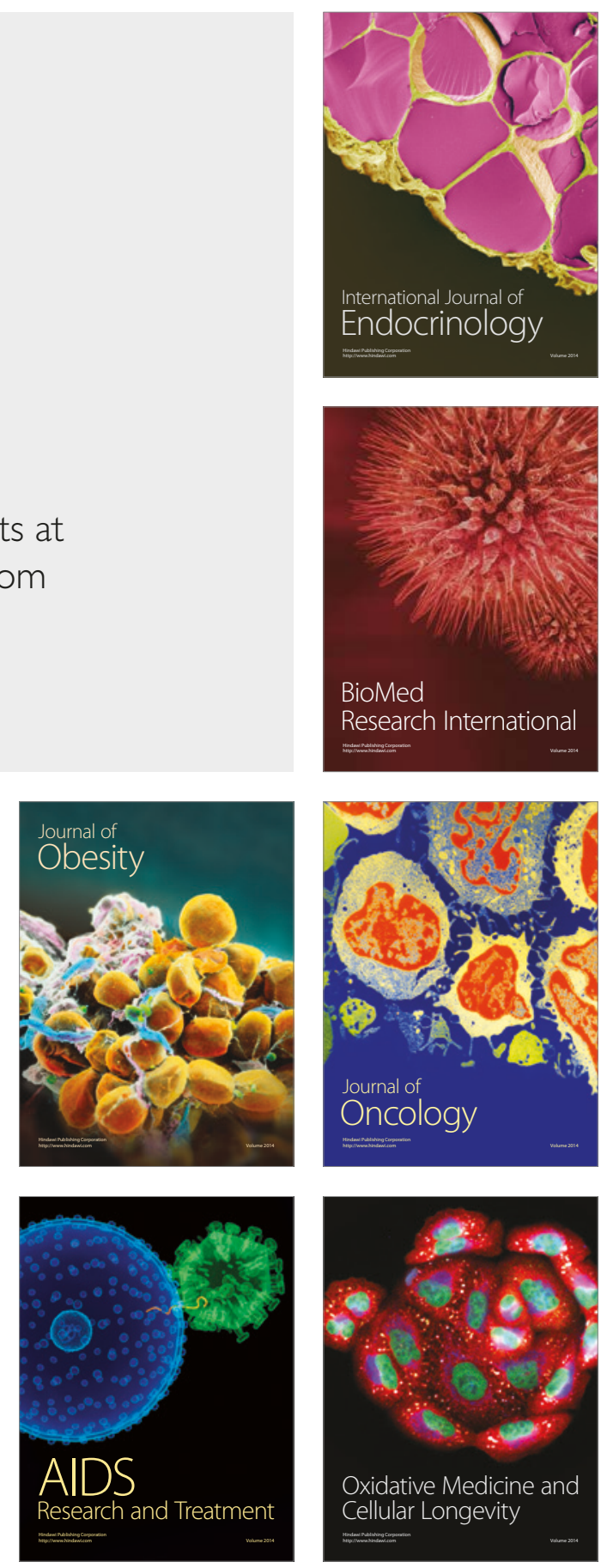